\title{
Elissa Bemporad. Legacy of Blood: Jews, Pogroms, and Ritual Murder in the Lands of the Soviets.
}

Oxford University Press, 2019. ISBN: 9780190466459. 252 p.

DOI: $10.31168 / 2658-3364.2020 .2 .20$

Эта книга Элиссы Бемпорад продолжает ее исследования истории евреев в СССР с особым фокусом на формирование советско-еврейской идентичности. В 2013 вышла ее монография «Becoming Soviet Jews: The Bolshevik Experiment in Minsk» [Bemporad 2013]. В «Legacy of Blood» исследовательница рассматривает проблему антиеврейского насилия на территории Советского Союза, антисемитизма и юдофобии. Название книги («Наследие крови») выбрано в связи с ключевым вопросом, который ставит Бемпорад: как и в каком виде Советский Союз унаследовал от царской России антиеврейские стереотипы и агрессию.

Тематически монография делится на две части. Первая - погромы: какую роль они сыграли в советско-еврейских отношениях, как к ним относилось советское руководство на словах и по факту, как их использовали в пропагандистских целях. Вторая - кровавый навет. Исследовательница анализирует трансформацию нарратива о кровавом навете в период от Октябрьской революции до 1950-х годов.

Бемпорад приводит редкие архивные данные: протоколы судебных заседаний по делам об антисемитизме, заявления против евреев с обвинениями в ритуальном убийстве, воспоминания о погромах. Эта информация имеет огромное значение для создания полного и объективного представления о положении евреев в СССР.

Первая глава книги называется «Погромы Гражданской войны и советско-еврейский союз». В ней Бемпорад заявляет интересный тезис: именно погромы обеспечили лояльность евреев советскому режиму, «сделали евреев советскими» [Bemporad 2019, 20]. Она доказывает, что для большой части еврейского населения отношение к новой власти изменилось в 1919 г. Если до этого многие евреи проявляли недоверие к 
большевикам, то «к концу 1919 года они начали воспринимать власть большевиков как источник защиты» [Bemporad 2019, 20].

На примере нескольких погромов на территории Украины, архивных данных и воспоминаний выживших Бемпорад показывает, как происходил процесс смены политической ориентации. Погромы периода Гражданской войны отличались беспрецедентными масштабами и жестокостью. Но самым неожиданным в них оказалось то, что «погромы дестабилизировали связи между евреями и их соседями, ухудшив в целом мирный баланс, существовавший до 1918 года» [Bemporad 2019, 24]. После погромов, в которых многие евреи теряли всех близких, оставаться в родном городе становилось бессмысленно, чувство причастности оказывалось утраченным. Это мотивировало евреев переезжать в крупные города. Кроме того, евреи охотно записывались добровольцами в Красную армию. Армия обещала им возможность отомстить погромщикам, давала надежду на возмездие и справедливость. Бемпорад приводит в качестве примера автобиографическую повесть Ицика Кипниса, который пережил погром в Проскурове в 1919 году и ушел в армию.

Отдельное внимание исследовательница уделяет женскому опыту погромов. Она пишет о погроме в Фастове в 1919 г., в ходе которого случились массовые публичные изнасилования. Для выживших женщин только отъезд из места насилия, разрыв со своим прошлым мог стать способом преодоления травмы. В 2018 г. Элисса Бемпорад участвовала в издании сборника статей «Women and Genocide» [Bemporad, Warren, 2018], и изучение специфического женского опыта военных конфликтов входит в сферу ее научных интересов.

Вторая глава посвящена отношению к кровавому навету в первые годы после революции. В качестве центрального case study выбраны процессы над лицами, причастными к «делу Бейлиса». Большевики выбрали этот случай в качестве показательных процессов за разжигание национальной розни и погромную деятельность. «Как только они [большевики] заняли Киев в феврале 1918, они арестовали Веру Чеберяк, главу киевской криминальной группировки, ответственной за убийство мальчика и фабрикацию дела против Менделя Бейлиса» [Bemporad 2019, 37]. Чеберяк, а также бывший министр юстиции Иван Щегловитов, инициировавший «дело Бейлиса», и начальник департамента полиции Степан Белецкий получили смертные приговоры.

Бемпорад подробно останавливается на процессе над обвинителем по «делу Бейлиса» Оскаром Виппером и считает его своего рода переломным. Решение суда (смертный приговор, заменен на заключение в концлагерь) и речь прокурора «символизировали конец того, что когда-то было социально и культурно приемлемым» [Bemporad 2019, 38]. То есть веры в кровавый навет, обвинений евреев в ритуальных убийствах и даже допущения такой возможности. 
Однако, вопреки четкой позиции властей, кровавый навет не исчез, а продолжил бытовать среди различных групп населения. В 1922 г. в Москве милиция предотвратила вспышку антиеврейского насилия, вызванного слухами о ритуальном убийстве. Это позитивный пример того, как советский режим мог защитить евреев от проявлений народной юдофобии. Тема кровавого навета активно использовалась в советской пропаганде в рамках борьбы с религией вообще, так как кровавый навет активно циркулировал среди церковных лидеров и верующих христиан.

Бемпорад также приводит примеры, когда власть на местах закрывала глаза на обвинения евреев в ритуальных убийствах и даже негласно поддерживала их.

Третья глава «Погромы как советские (еврейские) места памяти» анализирует проблему мемориализации погромов. Спустя несколько лет после окончания Гражданской войны еврейские общественные деятели проявляли инициативы увековечить память жертв погромов. В начале 1920-х годов советская власть активно поддерживала такие идеи. Однако довольно быстро пропаганда стала расставлять акценты так, чтобы картина соответствовала коммунистической парадигме. Например, писать о том, что жертвами погромов были только еврейские рабочие и крестьяне, в то время как богатые евреи находились в сговоре с лидерами погромщиков [Bemporad 2019, 70]. Национальный конфликт превратился в нарратив о классовой борьбе. Еврейская идентичность жертв погромов часто стиралась в публикациях в прессе, как и специфическая антиеврейская направленность актов насилия. «Со временем советское обещание помнить о погромах ослабло и утратило силу, а убийства евреев растворились в мешанине бандитизма, вандализма и контр-революции» [Bemporad 2019, 69]. В советской культуре погромы стало принято считать эпизодом победоносной войны за светлое будущее. Оплакивание и скорбь воспринимались как упадничество.

Четвертая глава описывает, как обвинения в ритуальных убийствах продолжились во время большого террора. Бемпорад показывает, как атмосфера массовых доносов и задержаний неожиданно дала новую жизнь кровавому навету: «Террор сделал даже самые диковинные обвинения правдоподобными: если преданный коммунист мог быть объявлен японским шпионом, то и евреи могли быть, конечно, обвинены в <..> убийстве христиан в ритуальных целях» [Bemporad 2019, 89].

Причину, по которой антисемитские стереотипы распространились снова, Бемпорад видит в миграции населения из деревни в город. Бывшие крестьяны привозили с собой традиционные верования, в том числе юдофобские представления.

Далее Бемпорад анализирует своеобразное перевоплощение кровавого навета в атеистической критике ритуалов, связанных с кровью: 
обрезания и кошерного забоя животных. Новый советский антисемитизм сместил фокус с евреев как нации на иудаизм.

Пятая глава посвящена истории погромов в СССР в 1930-1940-е гг. и отрицанию их существования советскими властями. Во время Второй мировой войны всплеск антиеврейского насилия был спровоцирован нацистской пропагандой, а также общей ситуацией социально-экономического кризиса. Но, в отличие от 1920-х годов, в 1940-е годы власти не стремились наказывать виновных. Официальная позиция была такова: в СССР нет антисемитизма, следовательно, не может быть погромов. Замалчивание этой проблемы повлияло на подъем антисемитизма уже на государственном уровне в конце 1940-х годов.

Последняя глава книги, «От каннибализма к политическому убийству», рассматривает случаи кровавого навета в 1940-1950-е гг. Старый антисемитский миф смешался с ненавистью к большевикам, среди которых было много евреев, в некоторых регионах страны (западная Украина, Узбекистан). Бемпорад также подробно останавливается на деле врачей, называя его «делом Бейлиса в атомную эпоху» [Bemporad 2019:136].

Исследование Элиссы Бемпорад прослеживает динамику антиеврейского насилия в Советском Союзе. Вывод, к которому приводит автор: несмотря на официальную борьбу с антисемитизмом, он продолжал существовать на уровне общества и государства в новых вариациях. Анализ источников и фактического материала дает цельное представление о сложных взаимоотношениях евреев и советской власти.

\title{
Литература
}

Bemporad 2013 - Bemporad E. Becoming Soviet Jews: The Bolshevik Experiment in Minsk. Bloomington: Indiana University Press, 2013. 276 p.

Bemporad, Warren 2018 - Women and Genocide: Survivors, Victims, Perpetrators / Eds. E. Bemporad and J.W. Warren. Bloomington: Indiana University Press, 2018. 344 p.

Bemporad 2019 - Legacy of Blood: Jews, Pogroms, and Ritual Murder in the Lands of the Soviets. Oxford: Oxford University Press, 2019. 252 p.

\author{
Ekaterina Kuznetsova (Berlin, Germany) \\ MA, Yiddish Studies \\ E-mail: katerina.kuznetsova1989@gmail.com \\ ORCID: 0000-0002-0198-7199
}

